\title{
Protective and Therapeutic Effects of Beta Glucan Administration on Experimental Ulcerative Colitis Model Induced by TNBS
}

\author{
TNBS ile Oluşturulan Deneysel Ülseratif Kolit Modelinde Beta Glukan Uygulamasının Koruyucu \\ ve Terapötik Etkileri
}

\author{
Deren TOKMAK ${ }^{1}$ \\ (D) 0000-0002-7953-8684 \\ Ferhat ŞİRINYILDIZ ${ }^{2}$ \\ (D) 0000-0001-8800-9787 \\ Rauf Onur EK ${ }^{3}$ \\ (D) 0000-0003-3923-0156
}

\begin{abstract}
Aim: In this study, it was aimed to investigate the effects of beta glucan (BG) on the experimental colitis model created by using trinitrobenzene sulfonic acid (TNBS).

Material and Methods: Thirty-two Wistar Albino rats were divided equally into four groups as sham control, TNBS, TNBS-BG3, and TNBS-BG10 groups. While saline was administrated to sham group, TNBS was administered intrarectally to the TNBS groups under anesthesia. BG was administered at a dose of $100 \mathrm{mg} / \mathrm{kg}$ by oral gavage, intragastrically, for 3 days $($ TNBS+3) to the TNBS-BG3 group and for 10 days $(7+$ TNBS+3) to the TNBS-BG10 group. At the end of the study, macroscopic, histological and biochemical tests were applied to the colon tissues taken.

Results: It was determined by histopathological scoring and biochemical results that BG administration caused positive effects on colon damage due to colitis. Malondialdehyde level and myeloperoxidase activity were found to be significantly higher in the TNBS group compared to the other groups $(\mathrm{p}=0.003$ and $\mathrm{p}<0.001$, respectively). Antioxidant levels increased in BG treated groups compared to TNBS group. While this increase was statistically significant among glutathione levels $(\mathrm{p}<0.001)$, it was not statistically significant in catalase enzyme activity $(\mathrm{p}=0.218)$. BG administration reduced the increase in lipid peroxidation and leukocyte infiltration level in the colon tissue. Positive changes due to the prophylactic effect of BG were determined in histological and biochemical results.

Conclusion: BG administration has been found to show anti-inflammatory and antioxidant properties, and $\mathrm{BG}$ has a treatment potential in reducing colon tissue damage due to TNBS-induced colitis.

Keywords: Anti-inflammatory; antioxidant; beta glucan; ulcerative colitis.
\end{abstract}

\section{ÖZ}

Amaç: $\mathrm{Bu}$ çalışmada trinitrobenzen sülfonik asit (TNBS) kullanılarak oluşturulan deneysel kolit modeli üzerinde beta glukan (BG)'ın etkilerinin araştırılması amaçlanmıştır.

Gereç ve Yöntemler: Otuz iki Wistar Albino sıçan eşit olarak sham kontrol, TNBS, TNBS-BG3 ve TNBS-BG10 gruplarına ayrılmıştır. Sham grubuna serum fizyolojik uygulanırken, TNBS gruplarına anestezi altında intrarektal yol ile TNBS uygulanmıştır. BG $100 \mathrm{mg} / \mathrm{kg}$ dozunda, TNBS-BG3 grubuna 3 gün (TNBS+3) süreyle, TNBS-BG10 grubuna ise 10 gün $(7+\mathrm{TNBS}+3)$ süreyle, intragastrik şekilde oral gavaj yolu ile verilmiştir. Çalışmanın sonunda alınan kolon dokularına makroskobik, histolojik ve biyokimyasal testler uygulanmıştır.

Bulgular: BG uygulamasının kolite bağlı kolon hasarında olumlu etkilere neden olduğu, histopatolojik skorlama ve biyokimyasal sonuçlar ile tespit edilmiştir. Malondialdehid seviyesi ve miyeloperoksidaz aktivitesinin diğer gruplar ile karşılaştırıldığında TNBS grubunda, anlamlı derecede yüksek olduğu tespit edilmiştir (sırasıyla $p=0,003$ ve $p<0.001$ ). BG tedavisi uygulanan gruplarda, antioksidan düzeyi TNBS grubuna göre artış göstermiştir. $\mathrm{Bu}$ artış glutatyon düzeyleri arasında istatistiksel olarak anlamlı iken $(p<0.001)$, katalaz enzim aktivitesinde istatistiksel olarak anlamlılık ortaya çıkmamıştır $(\mathrm{p}=0.218)$. BG uygulaması, kolon dokusundaki lipit peroksidasyon ve lökosit infiltrasyon düzeyindeki artışı azaltmıştır. Histolojik ve biyokimyasal sonuçlarda BG'nin profilaktik etkisine bağlı olarak olumlu değişiklikler tespit edilmiştir.

Received / Geliş Tarihi : 05.09.2021 Sonuç: BG uygulamaşnın anti-inflamatuar ve antioksidan özellikler gösterdiği tespit

$\begin{array}{ll}\text { Accepted / Kabul Tarihi : 18.11.2021 edilmiştir ve TNBS ile indüklenen kolit sonucu oluşan kolon doku hasarını azaltmada BG } \\ \text { Available Online / } & \text { tedavi edici potansiyel taşımaktadır. }\end{array}$ Available Online /

Çevrimiçi Yayın Tarihi : 03.12.2021
Anahtar kelimeler: Anti-inflamatuar; antioksidan; beta glukan; ülseratif kolit. 


\section{INTRODUCTION}

Inflammatory bowel disease (IBD) is a group of diseases of unknown etiology, caused by genetic, environmental and immunological causes. IBD is a disease that affects the gastrointestinal system with chronic, widespread, recurrent gastrointestinal inflammation and has a clinical course with intestinal and extra-intestinal involvement (1). IBD gathers ulcerative colitis and Crohn's disease, although these two diseases have similar clinical course and treatment methods; complications differ from each other in that they are localized to different parts of the intestine (2). In the pathogenesis of IBD, the effect of reactive oxygen species (ROS) on the increase of tissue damage in many inflammatory disease groups, including colitis, has been found $(3,4)$. Mucosal damage in IBD causes leukocyte migration to the intestinal mucosa. As a result of neutrophil and macrophage infiltration, oxidative damage in the mucosa increases and the increase in leukocyte migration together with the release of proinflammatory cytokines turns into a vicious circle (5). In ulcerative colitis, inflammation generally starts from the rectal mucosa and progresses uninterruptedly proximally and is observed as a disease that keeps the mucosa without bypassing (6). Environmental factors, genetic predisposition, changes in intestinal microflora and immunological response are thought to play a role in the etiopathogenesis of IBD (7). ROS contribute to the destruction of the mucosal barrier by disrupting the protective layer in the colonic epithelial tissue. It causes leukocyte infiltration and passage of bacterial toxins into the lamina propria (8).

Although oxidative activities continue in the body, antioxidant capacity, which is one of the body's defense mechanisms, protects tissues from ROS under physiological conditions. However, when the production rates of oxygen radicals exceed the capacity of the endogenous antioxidant defense mechanisms, they can destroy the tissue. Endogenous mechanisms for defense have many radical scavengers and enzymes, including catalase (CAT), glutathione (GSH), superoxide dismutase and peroxidases (8-11). Free oxygen radicals cause lipid membrane peroxidation, damage to protein and DNA, and damage to cells and tissues. Neutrophil migration in inflamed tissue facilitates the emergence of strong cytotoxic oxidants with the effect of myeloperoxidase (MPO) enzyme (12).

Beta glucan (BG) is a polysaccharide found in baker's yeast, cereals and fungi, and is involved in the structure of the cell wall (13). When BG is taken orally, it is absorbed from the gastrointestinal tract and plays a role in stimulating the immune system by binding to receptors on macrophages, neutrophils, and natural killer cells $(14,15)$. It is known that BG has antioxidant properties and increases the level of antioxidant enzymes and reduces oxidant substances (16). It has been understood that BGs stimulate collagen tissue synthesis by increasing NF-1 activity in fibroblasts and play a role in wound healing by increasing the amount of procollagen mRNA and type 1 and type 3 collagen levels (17).

In this study, the antioxidant and anti-inflammatory effects of $\mathrm{BG}$ given by gastric gavage were investigated in an experimental colitis model created with trinitrobenzene sulphonic acid (TNBS), by measuring histopathological evaluations, and malondialdehyde (MDA), MPO, CAT, and GSH levels in the colon tissue by ELISA method.

\section{MATERIAL AND METHODS}

The studies were carried out using 32 Wistar Albino female rats aged between 8 and 10 weeks, after the approval which was obtained from the Experimental Research Ethics Committee of Aydin Adnan Menderes University, dated 14.08.2015 and numbered $64583101 / 2015 / 094$. The rats were randomly divided into 4 equal experimental groups as sham group, TNBS group, TNBS-BG3 group, and TNBS-BG10 group. Except for the rats in the sham group, all subjects were exposed to experimental colitis.

2,4,6-trinitrobenzene sulphonic acid, purchased from Sigma company (Sigma, La Verpaillere, France) and prepared by dissolving $25 \mathrm{mg}$ in $37 \%$ ethanol, BG is Imuneks brand (Imuneks brand (Sigma, La Verpaillere, France) isolated from Saccharomyces cerevisiae). Mustafa Nevzat İlaç San. A.Ş., Istanbul, Turkey) was prepared by dissolving the preparation in drinking water.

\section{Induction of Colitis}

Animals that will cause colitis with TNBS were fasted 24 hours before the application and their colons were emptied by triggering the defecation reflex. Intrarectal administrations were given under ketamine $(75 \mathrm{mg} / \mathrm{kg}$ ) and xylazine $(8 \mathrm{mg} / \mathrm{kg})$ anesthesia, by entering $0.8 \mathrm{ml}$ of TNBS through a polyethylene cannula $8 \mathrm{~cm}$ from the anal orifice. Animals in the sham group were given physiological saline instead of TNBS.

\section{Experimental Groups}

The groups were organized as given below.

Sham Control Group: Saline was administered rectally under ketamine and xylazine anesthesia through the cannula. The rats were sacrificed 3 days after this treatment.

TNBS Group: Experimental colitis was formed by rectally giving $25 \mathrm{mg}$ of TNBS dissolved in $0.8 \mathrm{ml} 37 \%$ ethanol through a cannula under ketamine and xylazine anesthesia. The rats were sacrificed 3 days after this treatment.

TNBS-BG3 Group: BG at a dose of $100 \mathrm{mg} / \mathrm{kg}$ was given intragastrically via an oral gavage needle for 3 days from TNBS administration to sacrification. After 3 days of treatment, the rats were sacrificed.

TNBS-BG10 Group: BG at a dose of $100 \mathrm{mg} / \mathrm{kg}$ was given intragastrically via an oral gavage needle for 7 days before TNBS administration and for 3 days until sacrification.

At the end of the experiment, the rats were sacrificed by the cervical dislocation method while under ketamine xylazine anesthesia. Columns approximately $10 \mathrm{~cm}$ long were cut open longitudinally, the tissue was washed with physiological saline and made ready for histopathological and biochemical examination.

\section{Histopathological Evaluation}

Histopathological evaluation was performed using standard tissue fixation and sectioning procedures. Colon tissue taken from rats was kept in $10 \%$ neutral formaldehyde. The fixation time was 24 hours, and the temperature was $4{ }^{\circ} \mathrm{C}$. Colon tissues were soaked in ethanol for dehydration and cleared in xylene. Paraffin blocks were used for embedding the tissues and $5 \mu \mathrm{m}$ thick random sections were taken using a microtome (Leica model RM 2135, Leica, Germany). Hematoxylin-eosin procedure was used for staining these sections and the stained sections were examined under a light microscope. 
Screenshots were captured using an Olympus DP20 digital camera connected to an Olympus BX51 microscope.

Changes in histopathological parameters were scored appropriately. The degree of change in the columns was evaluated on a scale of 0 to 3 (18): These scores mean: 0 , no change; 1 , slight damage; 2 , moderate damage; 3 , severe damage. The evaluated parameters with respect to the change were inflammatory cell infiltration, submucosal edema, mucosal hemorrhage, and damage/necrosis. Scoring of tissue samples was done by a blinded observer.

\section{Biochemical Evaluation}

A 2-cm segment of the colon was separated and used for biochemical evaluations. These tissues were homogenized in $\mathrm{pH} 7.050 \mathrm{mM}$ phosphate buffer at $0-4{ }^{\circ} \mathrm{C}(\mathrm{w} / \mathrm{v}=1 / 10)$. Analyzes were performed by ELISA method using kits from BioVision Incorporated, California, USA.

MDA Activity: Homogenized tissue samples and Biovision Lipid Peroxidation Colorimetric/Fluorometric Detection Kit were used for MDA level.

MPO Activity: Homogenized tissue samples and Biovision Myeloperoxidase Activity Colorimetric Detection Kit were used for MPO activity.

GSH Level: Homogenized tissue samples and Biovision Glutathione Fluorometric Detection Kit were used for GSH level.

CAT Activity: Homogenized tissue samples and Biovision Catalase Activity Colorimetric/Fluorometric Detection Kit were used for CAT activity.

\section{Statistical Analysis}

All statistical analyses were performed via IBM SPSS Statistics 22.0 (IBM Corp. Released 2013. IBM SPSS Statistics for Windows, Version 22.0. Armonk, NY: IBM Corp.). The distributions of biochemical measurements (GSH, MDA, CAT and MPO) were evaluated by the Shapiro-Wilk's test and skewness/kurtosis statistics.
Homogeneity of the variances among groups for these measurements were examined by Levene's test. All these measurements were provided by mean \pm standard deviation $($ mean $\pm \mathrm{SD})$. The four groups were compared with respect to the biochemical measurements by ANOVA. Tukey's HSD test was performed, if necessary. A p-value $<0.05$ was accepted as statistically significant.

\section{RESULTS \\ Histopathological Results}

The histopathological results are given in Table 1. No damage was detected in the sham control group (Figure 1). In the colitis group, intense mucosal damage and necrosis, moderate inflammation, edema, and hemorrhage were detected (Figure 2). Moderate mucosal damage, inflammation, and hemorrhage were seen in the TNBS-BG3 group (Figure 3). Although there was no necrosis in the TNBS-BG10 group, mild edema and inflammation were detected (Figure 4).

\section{Biochemical Results}

The results of the biochemical measurements are given in Table 2. Accordingly, GSH level $(\mathrm{p}<0.001)$, MDA level $(\mathrm{p}=0.003)$ and MPO activity $(\mathrm{p}<0.001)$ showed statistically significant difference between groups, while CAT activity was found to be similar between groups $(\mathrm{p}=0.218)$. The post-hoc test revealed that the mean GSH level was significantly higher in sham group compared to all other groups (all p values <0.001) and in TNBS-BG10 group compared to TNBS group ( $\mathrm{p}=0.018)$. The mean MDA level and mean MPO activity in sham group ( $\mathrm{p}=0.008$ and $\mathrm{p}<0.001$, respectively), and also in TNBS-BG10 group ( $\mathrm{p}=0.005$ and $\mathrm{p}=0.014$, respectively) were significantly lower than those in TNBS group. There was also a significant difference between sham group and TNBS-BG3 group, indicating lower MPO activity in sham group $(\mathrm{p}=0.037)$.

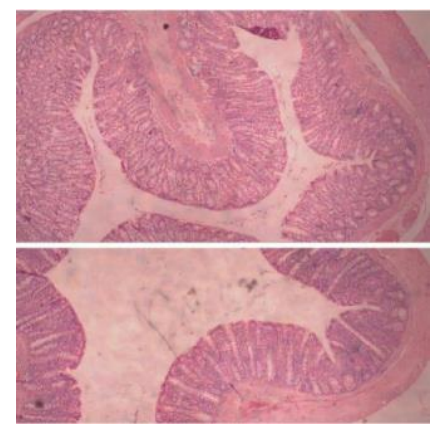

Figure 1. Histopathological features of the tissue of the sham control group (10X-40X) TNBS group (10X-40X)

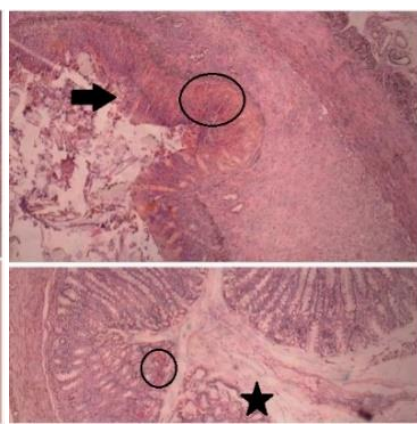

Figure 3. Histopathological features of the tissue of the TNBS-BG3 group (10X-40X) TNBS-BG10 group (10X-40X)

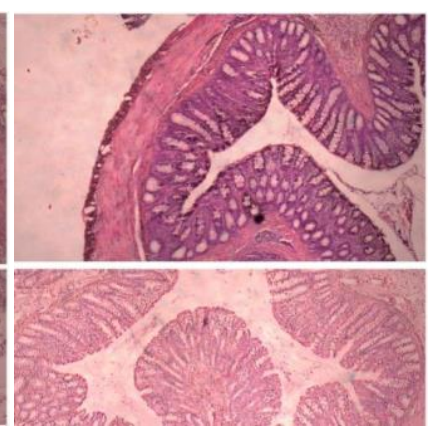

Figure 4. Histopathological features of the tissue of the

Table 1. The histological (microscopic) scores for each parameter in groups

\begin{tabular}{lcccc}
\hline & Sham Control & TNBS & TNBS-BG3 & TNBS-BG10 \\
\hline Mucosal Damage / Necrosis & 0 & 3 & 2 & 0 \\
Inflammation & 0 & 2 & 2 & 1 \\
Edema & 0 & 2 & 1 & 1 \\
Hemorrhage & 0 & 2 & 2 & 0 \\
\hline
\end{tabular}

TNBS: trinitrobenzene sulfonic acid, BG: beta glucan 
Table 2. Comparison of the biochemical measurements between groups

\begin{tabular}{lccccc}
\hline & Sham Control & TNBS & TNBS-BG3 & TNBS-BG10 & p \\
\hline GSH $(\mathrm{nmol} / \mathrm{mg})$, mean \pm SD & $16.575 \pm 2.629$ & $9.304 \pm 1.085$ & $11.463 \pm 1.885$ & $12.238 \pm 1.411$ & $<\mathbf{0 . 0 0 1}$ \\
MDA $(\mathrm{nmol} / \mathrm{g})$, mean $\pm \mathrm{SD}$ & $239.538 \pm 19.715$ & $265.600 \pm 12.762$ & $252.263 \pm 11.951$ & $238.350 \pm 13.748$ & $\mathbf{0 . 0 0 3}$ \\
CAT $(\mathrm{mU} / \mathrm{ml})$, mean $\pm \mathrm{SD}$ & $4.540 \pm 0.664$ & $4.116 \pm 0.956$ & $3.918 \pm 0.740$ & $3.762 \pm 0.635$ & 0.218 \\
MPO $(\mathrm{U} / \mathrm{g})$, mean $\pm \mathrm{SD}$ & $10.131 \pm 1.427$ & $13.683 \pm 1.176$ & $12.129 \pm 1.605$ & $11.393 \pm 1.333$ & $<\boldsymbol{0 . 0 0 1}$
\end{tabular}

TNBS: trinitrobenzene sulfonic acid, BG: beta glucan, GSH: glutathione, MDA: malondialdehyde, CAT: catalase, MPO: myeloperoxidase, SD: standard deviation, Tukey HSD post hoc test results: GSH; Sham vs TNBS: $\mathrm{p}<0.001$, Sham vs TNBS-BG3: $\mathrm{p}<0.001$, Sham vs TNBS-BG10: $\mathrm{p}<0.001$, TNBS vs TNBS-BG3: $\mathrm{p}=0.113$, TNBS vs TNBS-BG10: $\mathrm{p}=0.018$, TNBS-BG3 vs TNBS-BG10: $\mathrm{p}=0.835$; MDA; Sham vs TNBS: $\mathrm{p}=0.008$, Sham vs TNBS-BG3: $\mathrm{p}=0.336$, Sham vs TNBS-BG10: $\mathrm{p}=0.999$, TNBS vs TNBS-BG3: $\mathrm{p}=0.397$, TNBS vs TNBS-BG10: $\mathrm{p}=0.005$, TNBS-BG3 vs TNBS-BG10: $\mathrm{p}=0.263$; MPO; Sham vs TNBS: $\mathrm{p}<0.001$, Sham vs TNBS-BG3: $\mathrm{p}=0.037$, Sham vs TNBS-BG10: $\mathrm{p}=0.290$, TNBS vs TNBS-BG3: $\mathrm{p}=0.140$, TNBS vs TNBS-BG10: $\mathrm{p}=0.014$, TNBS-BG3 vs TNBS-BG10: $\mathrm{p}=0.718$

\section{DISCUSSION}

In this study, we found that the mean GSH and CAT levels were significantly higher in sham group compared to others. Also, MPO and MDA levels were significantly lower in sham group compared to others. This indicates that oxidative damage was observed in the biochemical results of the TNBS-treated groups. Furthermore, histological examination results support the biochemistry results. Oxidative damage and histological tissue damage decreased with BG administration.

Jurjus et al. (19) reported that the inflammatory process and wound development in TNBS colitis may be due to disruption of the intestinal mucosal barrier depending on the dose of the chemical applied. Likewise, Millar et al. (20) reported that widespread mucosal edema, necrosis and ulcerations were observed in the TNBS colitis model. In addition, according to current studies, Xue et al. (21) used the chemical Oxazolone to induce experimental ulcerative colitis. Shanmugam et al. (22) used indomethacin, and Motawea et al. (23) and Guazelli et al. (24) used acetic acid for induction of colitis. Their results support the results of TNBS-induced ulcerative colitis and our results. Significant histopathological changes were detected in all experimental groups in which colitis was induced by TNBS colitis model used in our study. Among the TNBS-treated groups, necrosis and hemorrhage were not observed in the mucosa in the TNBS-BG10 group, and inflammation was observed to be more limited than in the other TNBS-treated groups.

Nosál'ová et al. (25) reported that $\mathrm{N}$-acetyl cysteine treatment showed antioxidant properties in acetic acid-induced colitis model. Ademoğlu et al. (26), on the other hand, investigated the antioxidant effects of vitamin $\mathrm{E}$ and selenium on ulcerative colitis in their experimental study and concluded that MDA decreased significantly in the experimental group given vitamin $\mathrm{E}$ and selenium together. Ek et al. (27) determined that caffeic acid phenethyl ester (CAPE) administered to rats with colitis with TNBS caused a decrease in MPO levels in the treatment group. Ige et al. (28) in their study in which they associated the effects of ulcerative colitis induced by acetic acid with maize consumed in the diet, showed that while the MPO values of the colitis group increased significantly compared to the control group, the MPO levels of the rats fed a diet supplemented with maize at an appropriate rate approached the values of the control group. Motawea et al. (23), in their study investigating the effects of oleuropein against acetic acid-induced ulcerative colitis, found that MDA and MPO levels, which increased significantly in the colitis group, decreased in the oleuropein-administered groups and approached the results of the control group. With our study findings, it was observed that $\mathrm{BG}$ reduced lipid peroxidation with its antioxidant property, and the lowest MDA level was found in the TNBS-BG10 group. In addition, a statistically significant increase was found in the colon tissue MPO activity values in the colitis group, which was applied TNBS, and it was observed that the values approached the control group with the treatment.

Karabeyoglu et al. (29) examined the effect of ethyl pyruvate in the experimental colitis model created in rats and studied the glutathione levels in the colon tissue to investigate the antioxidant property of ethyl pyruvate. GSH levels in the treatment group were found to be significantly higher than in the plain colitis group. Shanmugam et al. (22) in their study investigating the effects of Passiflora subpeltata Ortega on experimental colitis, found that the GSH levels, which decreased significantly in the colitis group, increased with the administration of Passiflora subpeltata Ortega depending on the dose they applied. Kuralay et al. (30) reported that CAT activity did not change with colitis in acetic acid-induced colitis model. In the study conducted by Yildiz et al. (31), it was found that there was no significant difference in CAT levels between the colitis group and the treatment group in which resveratrol was applied in the colitis model induced by TNBS. In our study, no statistically significant difference was found between the groups in terms of CAT levels. The inability to detect a change in CAT level is due to the more effective functioning of other cellular antioxidant systems. Şener et al. (32) investigated the antioxidant properties of $\mathrm{BG}$ and its protective role against oxidative organ damage in the heart, brain, kidney and liver in rats in which they caused sepsis as a result of cecal ligation and piercing and observed that it reduced TNF- $\alpha$ levels in the organs after sepsis. Kayali et al. (33) stated that $\beta$-glucan reduces oxidative damage in experimentally induced spinal cord injury, Şener et al. (34) investigated the protective and therapeutic effects of $\beta$-glucan on bladder and kidney tissues in their study of nicotine-induced oxidative damage. They found that the events increase the activities of antioxidant enzymes. Tatli-Seven et al. (35) investigated the effects of BG against lead acetate-induced hepatic damage and reproductive damage and determined that it showed protective and healing properties against different tissues and organs.

\section{CONCLUSION}

In the results obtained in our study, the antioxidant effect of $\beta$-glucan was found to be compatible with the literature. $\mathrm{BG}$ increased the level of glutathione, which is an indicator 
of antioxidant parameter, decreased the levels of MDA and MPO, and caused improvement in histopathological scores. In this way, it has been shown by our study that BG can be a therapeutic agent. Treatment with BG has the potential to reduce colon tissue damage in TNBS-induced colitis in rats. Therefore, with these features, BG can be considered as a new and effective adjunctive therapy in the prevention and treatment of IBD.

Ethics Committee Approval: The study was approved by the Ethics Committee of Aydin Adnan Menderes University (14.08.2015, 64583101/2015/094).

Conflict of Interest: None declared by the authors.

Financial Disclosure: This study was supported by Aydin Adnan Menderes University, Scientific Research Projects Committee as master thesis (Project code: TPF-13021).

Acknowledgements: This study was supported by Aydin Adnan Menderes University, Scientific Research Projects Committee as master thesis (Project code: TPF-13021). We thanks to Cenk Orak and Esra Gökmen Y1lmaz for their support during the laboratory phase, and Afra Alkan for her professional assistance in biostatistical evaluation.

Author Contributions: Idea/Concept: DT, ROE; Design: DT, FŞ, ROE; Data Collection/Processing: DT, FŞ; Analysis/Interpretation: DT, FŞ; Literature Review: DT; Drafting/Writing: DT, FŞ; Critical Review: FŞ, ROE.

\section{REFERENCES}

1. Petronis A, Petroniene R. Epigenetics of inflammatory bowel disease. Gut. 2000;47(2):302-6.

2. Gasche C, Scholmerich J, Brynskov J, D’Haens G, Hanauer SB, Irvine EJ, et al. A simple classification of Crohn's disease: report of the Working Party for the World Congresses of Gastroenterology, Vienna 1998. Inflamm Bowel Dis. 2000;6(1):8-15.

3. Norris AA, Lewis AJ, Zeitlin IJ. Changes in colonic tissue levels of inflammatory mediators in a guinea-pig model of immune colitis. Agents Actions. 1982;12(12):243-6.

4. Selve N. Chronic intrajejunal TNBS application in TNBS-sensitized rats: a new model of chronic inflammatory bowel diseases. Agents Actions. 1992;Spec No:C15-7.

5. Podolsky D. Inflamatory bowel disease. N Engl J Med. 2002;347(6):417-29.

6. Ordás I, Eckmann L, Talamini M, Baumgart DC, Sandborn WJ. Ulcerative colitis. Lancet 2012;380(9853):1606-19.

7. Kaser A, Zeissig S, Blumberg RS. Inflammatory bowel disease. Annu Rev Immunol. 2010;28:573-621.

8. Grisham MB, Granger DN. Neutrophil-mediated mucosal injury. Role of reactive oxygen metabolites. Dig Dis Sci. 1988;33(3 Suppl):6S-15S.

9. Campbell-Thomson M, Lynch IJ, Bhardwaj B. Expression of estrogen receptor (ER) subtypes and ER beta isoforms in colon cancer. Cancer Res. 2001;61(2):632-40.
10. Konstantinopoulos PA, Kominea A, Vandoros G, Sykiotis GP, Andricopoulos P, Varakis I, et al. Oestrogen receptor beta (ERbeta) is abundantly expressed in normal colonic mucosa, but declines in colon adenocarcinoma paralleling the tumour's dedifferentiation. Eur J Cancer. 2003;39(9):1251-8.

11. Wada-Hiraike O, Warner M, Gustafsson JA. New developments in oestrogen signalling in colonic epithelium. Biochem Soc Trans. 2006;34(Pt 6):1114-6.

12. Girgin F, Karaoglu O, Erkuş M, Tüzün S, Ozütemiz O, Dinçer C, et al. Effects of trimetazidine on oxidantantioxidant statusin trinitrobenzenesulfonic acid-induced chronic colitis. J Toxicol Environ Health. 2000;59(8):641-52.

13. Kim SY, Song HJ, Lee YY, Cho KH, Roh YK. Biomedical Issues of dietary fiber beta-glucan. J Korean Med Sci. 2006;21(5):781-9.

14. Zeković DB, Kwiatkowski S, Vrvić MM, Jakovljević D, Moran CA. Natural and modified (1-->3)-beta-Dglucans in health promotion and disease alleviation. Crit Rev Biotechnol. 2005;25(4):205-30.

15. Şener M, Canda E, Gürel D. Effects of enteral beta glucan in a rat model of short bowel on intestinal adaptation. Genel Tıp Derg. 2011;21(3):95-9. Turkish.

16. Bayrak O, Turgut F, Karatas OF, Cimentepe E, Bayrak $\mathrm{R}$, Catal F, et al. Oral beta-glucan protects kidney against ischemia/reperfusion injury in rats. Am $\mathrm{J}$ Nephrol. 2008;28(2):190-6.

17. Wei D, Zhang L, Williams DL, Browder IW. Glucan stimulates human dermal fibroblast collagen biosynthesis through a nuclear factor-1 dependent mechanism. Wound Repair Regen. 2002;10(3):161-8.

18. González R, Rodríguez S, Romay C, Ancheta O, González A, Armesto J, et al. Anti-inflammatory activity of phycocyanin extract in acetic acid-induced colitis in rats. Pharmacol Res. 1999;39(1):55-9.

19. Jurjus AR, Khoury NN, Reimund JM. Animal models of inflammatory bowel disease. J Pharmacol Toxicol Methods. 2004;50(2):81-92.

20. Millar AD, Rampton DS, Chander CL, Claxson AW, Blades S, Coumbe A, et al. Evaluating the antioxidant potential of new treatments for inflammatory bowel disease using a rat model of colitis. Gut. 1996;39(3):407-15.

21. Xue NN, He M, Li Y, Wu JZ, Du WW, Wu XM, et al. Periplaneta americana extract promotes intestinal mucosa repair of ulcerative colitis in rat. Acta Cir Bras. 2020;35(10):e202001002.

22. Shanmugam S, Thangaraj P, Dos Santos Lima B, Trindade GGG, Narain N, Mara de Oliveira E Silva A, et al. Protective effects of flavonoid composition rich P. subpeltata Ortega. on indomethacin induced experimental ulcerative colitis in rat models of inflammatory bowel diseases. $\mathrm{J}$ Ethnopharmacol. 2020;248:112350.

23. Motawea MH, Abd Elmaksoud HA, Elharrif MG, Desoky AAE, Ibrahimi A. Evaluation of antiinflammatory and antioxidant profile of oleuropein in experimentally induced ulcerative colitis. Int $\mathbf{J}$ Mol Cell Med. 2020;9(3):224-33.

24. Guazelli CFS, Fattori V, Ferraz CR, Borghi SM, Casagrande R, Baracat MM, et al. Antioxidant and anti-inflammatory effects of hesperidin methyl 
chalcone in experimental ulcerative colitis. Chem Biol Interact. 2021;333:109315.

25. Nosál'ová V, Cerná S, Bauer V. Effect of Nacetylcysteine on colitis induced by acetic acid in rats, Gen Pharmacol. 2000;35(2):77-81.

26. Ademoglu E, Erbil Y, Tam B, Barbaros U, Ilhan E, Olgac $\mathrm{V}$, et al. Do vitamin $\mathrm{E}$ and selenium have beneficial effects on trinitrobenzenesulfonic acid-induced experimental colitis. Dig Dis Sci. 2004;49(1):102-8.

27. Ek RO, Serter M, Ergin K, Yildiz Y, Cecen S, Kavak $\mathrm{T}$, et al. The effects of caffeic acid phenethyl ester (CAPE) on TNBS-induced colitis in ovariectomized rats. Dig Dis Sci. 2008;53(6):1609-17.

28. Ige SF, Adeniyi MJ, Olayinka AT, Kehinde IC. Role of dietary maize formulations in the healing of experimental acetic acid induced ulcerative colitis in male rats. Chin J Physiol. 2020;63(4):156-62.

29. Karabeyoglu SM, Bozkurt B, Unal B, Yilmaz OC, Bilgihan A, Atasay FO, et al. Results of ethyl pyruvate application in an experimental colitis model. Visc Med. 2008;24(2):162-6.

30. Kuralay F, Yildiz C, Ozutemiz O, Islekel H, Caliskan $\mathrm{S}$, Bingol B, et al. Effects of trimetazidine on acetic acid-induced colitis in female Swiss rats. J Toxicol Environ Health A. 2003;66(2):169-79.

31. Yildiz G, Yildiz Y, Ulutas PA, Yaylali A, Ural M. Resveratrol pretreatment ameliorates TNBS colitis in rats. Recent Pat Endocr Metab Immune Drug Discov. 2015;9(2):134-40.

32. Sener G, Toklu H, Ercan F, Erkanli G. Protective effect of beta-glucan against oxidative organ injury in a rat model of sepsis. Int Immunopharmacol. 2005;5(9):1387-96.

33. Kayali H, Ozdag MF, Kahraman S, Aydin A, Gonol E, Sayal A, et al. The antioksidant effect of beta-glucan on oxidative stress status in experimental spinal cord injury in rats. Neurosurg Rev. 2005;28(4):298-302.

34. Sener G, Toklu HZ, Cetinel S. $\beta$-Glucan protects against chronic nicotine-induced oxidative damage in rat kidney and bladder. Environ Toxicol Pharmacol. 2007;23(1):25-32.

35. Tatli Seven P, Iflazoglu Mutlu S, Seven I, Arkali G, Ozer Kaya S, Kanmaz OE. Protective role of yeast beta-glucan on lead acetate-induced hepatic and reproductive toxicity in rats. Environ Sci Pollut Res. 2021;28(38):53668-78. 